University of South Carolina

Scholar Commons

$12-1985$

\title{
The Intellectual Development of Modern Products Liability Law: A Comment on Priest's View of the Cathedral's Foundations
}

David G. Owen

University of South Carolina - Columbia, dowen@law.sc.edu

Follow this and additional works at: https://scholarcommons.sc.edu/law_facpub

Part of the Torts Commons

Recommended Citation

David G. Owen, The Intellectual Development of Modern Products Liability Law: A Comment on Priest's View of the Cathedral's Foundations, 14 J. Legal Stud. 529 (1985)

This Article is brought to you by the Law School at Scholar Commons. It has been accepted for inclusion in Faculty Publications by an authorized administrator of Scholar Commons. For more information, please contact digres@mailbox.sc.edu. 


\title{
THE INTELLECTUAL DEVELOPMENT OF MODERN PRODUCTS LIABILITY LAW: A COMMENT ON PRIEST'S VIEW OF THE CATHEDRAL'S FOUNDATIONS
}

\author{
DAVID G. OWEN*
}

$\mathrm{F}$ Ew scholars in recent years have seriously studied the intellectual history of modern products liability theory. Although the economics of the area has caught the fancy of many recent scholars, only a few writers have critically reviewed the original (and still conventional) rationales for strict manufacturer accountability for product accidents. ${ }^{1}$ Perhaps this lack of scholarly interest is attributable to the compelling force of the academic scholarship-spearheaded by James, Prosser, and others in the 1950 s and early 1960 s and elaborated in the late 1960 s and 1970 s by Wade, Keeton and others-which set firmly in place the now conventional rationales. ${ }^{2}$ Probably the lack of interest was reinforced by the rapid and overwhelming judicial acceptance of the doctrine and its standard rationales-led by Judge Francis in Henningsen in 1960 and Judge Traynor

* Visiting Professor of Law, University of Michigan; Professor of Law, University of South Carolina.

${ }^{1}$ See, for example, Alan Schwartz, Products Liability and Judicial Wealth Redistributions, 51 Ind. L. J. 558 (1976); Howard C. Klemme, The Enterprise Liability Theory of Torts, 47 Colo. L. Rev. 153 (1976); Richard A. Epstein, Modern Products Liability Law (1980); David G. Owen, Rethinking the Policies of Strict Products Liability, 33 Vand. L. Rev. 681 (1980).

2 The conventional rationales include: (1) representations of product quality by manufacturers inducing consumer expectations of product safety; (2) the powerlessness of consumers with respect to safety resulting from the complexity and diversity of products; (3) the power of manufacturers over product danger information and design; (4) probability of manufacturer negligence in producing defective products, yet difficulty for consumers to prove fault; (5) deterrence of product accidents (encouraging product safety); (6) risk spreading; and (7) forcing enterprises to internalize the costs of product accidents. See John E. Montgomery \& David G. Owen, Reflections on the Theory and Administration of Strict Tort Liability for Defective Products, 27 S.C. L. Rev. 803, 809-10 (1976).

[Journal of Legal Studies, vol. XIV (December 1985)] 
in Greenman ${ }^{3}$ in 1963 , certified by $\S 402 \mathrm{~A}$ of the Second Restatement of Torts in 1964, and spread by other judges across the land in the late 1960s and 1970s. This impressive convergence of academic and judicial thought appeared to demonstrate an ineluctable historical imperative, based on a variety of the familiar rationales, toward "enterprise liability" for product accidents. George Priest's masterful inquiry into the contributions of James and Kessler to the formation of certain of these rationales-risk spreading, manufacturer power, and cost internalization-adds a valuable dimension to the growing critique of modern products liability theory and doctrine.

Priest's paper is largely a retelling of the development of strict products liability in tort. Its principal value lies in its focus on the early contributions of James and Kessler. His review of James's arguments for risk distribution (and to a lesser extent cost internalization), and of Kessler's arguments for legal control of corporate power, gives important insights into the confluence of tort and contract theory that generated the modern concepts of enterprise liability.

While Priest's insights indeed advance our historical understanding of certain important theoretical underpinnings of modern products liability law and theory, their explanatory value is narrower than his paper suggests. "Intellectual histories" that focus on the contributions of a small number of legal scholars run the risk of telling us principally about the thinking of the chosen scholars, rather than providing a balanced study of the scholarship in the field. ${ }^{4}$ To be most useful, intellectual histories should define with caution the contribution of each such scholar, should recognize (even if only generally) the related contributions of other legal scholars, and should place all the work in its broader sociopolitical context.

Much less than in science are theories suddenly "invented" in the law. 5 Instead, most legal concepts evolve slowly from various strands of ideas. It is in fact the very nature of good scholarship that it derives from earlier

\footnotetext{
3 As Priest points out, one must look to the concurring opinion in Escola v. Coca Cola Bottling Co. of Fresno, 24 Cal. 2d 453, 461, 150 P.2d 436, 440 (1944), for Judge Traynor's principal articulation of the strict liability rationales. I have some trouble, however, with Priest's assertion that Traynor's concurring opinion was largely ignored in the scholarship of the early 1950s. See the masterful piece by Albert A. Ehrenzweig, Negligence without Fault (1951), reprinted in 54 Cal. L. Rev. 1422, 1473 (1966); see also William L. Prosser, Handbook of the Law of Torts $506 \mathrm{n} .1$ ( $2 \mathrm{~d}$ ed. 1955).

4 The best example of this approach of which I am aware is G. Edward White, Tort Law in America: An Intellectual History (1980).

5 See, for example, George P. Fletcher, Two Modes of Legal Thought, 90 Yale L. J. 970 , 1001 (1981).
} 
generations of writing and is enriched by strong cross-fertilization from other contemporary scholarship. With or without the help of Kessler, therefore, James did not "invent" the notion of enterprise liability or any of its underlying precepts, as Priest's paper might suggest. Instead, both scholars worked from and contributed to a rich intellectual mosaic. As Priest acknowledges, James did not invent the theories of risk distribution or cost internalization. Kessler and particularly James no doubt helped to shape and perhaps accelerate the evolving notion of applying enterprise liability concepts to the manufacture of defective products. My guess is, however, that Henningsen, Greenman, and $\S 402 \mathrm{~A}$ would have come to pass in any event, had James and Kessler never written a word-that their work was not in fact a sine qua non of the development of modern products liability law. In my judgment a solid social consensus, much bigger than two men, forged the triumph of modern products liability theory and doctrine.

Other legal scholars, other legal concepts, and other sociopolitical developments worked together to form and combine the various strands of theory underlying modern products liability law. By way of example, both Llewellyn (on the contracts side) and Prosser (on the torts side) deserve more credit than Priest affords them. Priest does not ignore their work, but often he understates its significance. He gives passing recognition to Llewellyn, but he does not give sufficient credit to Llewellyn's substantial early contributions on the warranty of quality. ${ }^{6}$ He gives some begrudging recognition to Prosser, but does not give due credit to Prosser's early articulation of the modern rationales. ${ }^{7}$ It may be true that James's scholarship in the products liability field during the 1950 s has received somewhat less attention over the years than it deserved. But in elevating so much the contributions of James and Kessler, Priest misleadingly diminishes those of Llewellyn, Prosser, and others.

The focus on two men leaves crucial gaps in the intellectual genealogy of products liability law. In using Kessler as the sole representative for the contract root of strict products liability, Priest's analysis leaves bare a fundamentally important intellectual branch of this area of the law: the warranty law concept that vendor misrepresentations may harm consumers by unfairly distorting their expectations of product quality. The notion that sellers should not be permitted so to trick consumers into paying "fair

${ }^{6}$ See K. N. Llewellyn, On Warranty of Quality and Society (pts. 1, 2), 36 Colum. L. Rev. 699 (1936); 37 Colum. L. Rev. 341 (1937). See generally William Twining, Karl Llewellyn and the Realist Movement (1973).

${ }^{7}$ See William L. Prosser, Handbook of the Law of Torts (1st ed. 1941), ch. 15, esp. at 689; id. (2d ed. 1955), ch. 17, esp. at 506-7. 
value" for goods that are other (more dangerous) than they are said or appear to be is the oldest and perhaps strongest root of modern products liability law. Its origins date at least from the ancient law of Rome; its influence continues through a strong ecclesiastical and secular tradition of medieval Europe, and takes firm root from an early date in the common law of England and the United States as a vital interest protected by the law both of tort and contract. ${ }^{8}$ As chronicled in the 1960 s by Prosser and others, the crumbling of the citadel of privity and the weakening of other contractual limitations on liability and damages (such as disclaimers, limitations on remedies, and the notice of breach requirement) had to occur before tort law could reabsorb the function of protecting consumers against the frustration of their expectations by seller misrepresentations of product quality. The strongly ethical flavor to this theory does not fit neatly into Priest's account of the rise of enterprise liability. But its influence on the developing law was powerful, ${ }^{9}$ even if this is not evident from the writings of James and Kessler.

In addition, Priest might have been more catholic in his historical reconstruction of the products liability law cathedral. His discussion of the impact of Nazi totalitarianism on Kessler sheds valuable light on Kessler's belief in the oppressiveness of manufacturer power. The history would also have benefited from at least a brief inquiry into the role of other contemporaneous trends in social and political thought, from the beliefs behind Roosevelt's New Deal liberalism to the evolving conceptions of social welfare, citizen entitlements, and corporate power and its abuse. It was probably more than mere coincidence that the electorate chose to cast its fate in 1960 with the liberal spirit of John F. Kennedy less than five months after the judiciary had decided to cast its fate with the liberal spirit of Henningsen v. Bloomfield Motors.

Intellectual currents were thus abroad, much wider than those expressed in the legal writings of James and Kessler, which must have

\footnotetext{
${ }^{8}$ See generally W. Page Keeton, David G. Owen, \& John E. Montgomery, Products Liability and Safety-Cases and Materials 19-26 (1980).

9 The consumer expectations thesis was explicated at an early date by Reed Dickerson in Products Liability and the Food Consumer 3-5 (1951), and more fully developed in Reed Dickerson, Products Liability: How Good Does a Product Have to Be? 42 Ind. L. Rev. 301 (1967). For more recent discussions, see Michael D. Bernacchi, A Behavioral Model for Imposing Strict Liability in Tort: The Importance of Analyzing Product Performance in Relation to Consumer Expectation and Frustration, 47 U. Cinn. L. Rev. 43 (1978); and the amusing effort by F. Patrick Hubbard, Reasonable Human Expectations: A Normative Model for Imposing Strict Liability for Defective Products, 29 Mercer L. Rev. 465 (1978). Shapo has exhaustively developed the representational thesis more recently. See Marshall S. Shapo, A Representational Theory of Consumer Protection: Doctrine, Function and Legal Liability for Product Disappointment, 60 Va. L. Rev. 1109 (1974).
} 
provided these and other legal scholars with important germs of thought to be distilled and formulated into legal concepts. The fit was surely very comfortable between the dominant political sentiments of the 1960 s and the belief of James and others that the economic burden of accidental injuries should be taken from individual "victims" and placed on institutions which could then "absorb" or pass them on through price increase "taxes" to the general society. If these concepts today seem in some ways naive and roughly constructed intellectually, they should in fairness be placed back to that time of enthusiastic optimism, dominated by assumptions validated by nearly two decades of experience: that the economic pie was growing much faster than the population; that society would be able to satisfy the economic wants of nearly all within another couple of decades (by 1985?); and that enterprise liability was but a brief rest stop on the short journey to a broad-based system of social health and welfare insurance. ${ }^{10}$ Certainly as predictions these perspectives have proved quite false. Yet as postulates they most likely influenced the early scholarship on enterprise liability, and they most certainly enhanced the largely uncritical acceptance of strict manufacturer liability by both the courts and commentators in the 1960 s.

Priest's penetrating account of the intellectual origins of the modern products liability law cathedral opens to the light at least two key concepts in its foundation: manufacturer insurance and manufacturer power. One should hope that the intellectual history of other aspects of modern products liability theory, particularly its roots in misrepresentation and consumer expectations, will be examined as carefully in the future by Priest or others. Once we understand more fully from where the conventional concepts came and what they really said we can begin to critique them more constructively, to extract what strands of intellectual value they may contain, and to discard the rest. Then will come the major task: to identify the social values that products liability law should protect and promote, and finally to construct a new cathedral of principles and rules on those firm foundations. Priest's valuable historical perspective on certain intellectual origins underlying modern products liability law advances in significant measure the journey to that end.

\footnotetext{
10 "Until Americans have a comprehensive scheme of social insurance, courts must resolve by a balancing process the head-on collision between the need for adequate recovery and viable enterprises. . . . This balancing task should be approached with a realization that the basic consideration involves a determination of the most just allocation of the risk of loss between the members of the marketing chain." Helene Curtis Industries, Inc. v. Pruitt, 385 F.2d 841, 862 (5th Cir. 1967) (citing Richard G. Wilson, Products Liability (pt. 2), The Protection of the Producing Enterprise, 43 Calif. L. Rev. 809 (1955)).
} 
. 